Short Note

\title{
Synthesis of 1-[(2-Oxonaphthalen-1(2H)-ylidene)methyl]urea
}

\section{Jiehua Xu, Anjun Chen and Qingjian Liu*}

College of Chemistry, Chemical Engineering and Materials Science

Engineering Research Center of Pesticide and Medicine Intermediate Clean Production

Ministry of Education, Shandong Normal University, Jinan 250014, P. R. China

* Author to whom correspondence should be addressed; E-mail: liuqj@sdnu.edu.cn

Received: 7 January 2009 / Accepted: 13 March 2009 / Published: 18 March 2009

\begin{abstract}
An unexpected product, 1-[(2-oxonaphthalen-1(2H)-ylidene)methyl]urea 4 of the condensation reaction of 2-hydroxy-1-naphthaldehyde with or without ethyl benzoylacetate and urea under hydrochloric acid-catalyzed and solvent-free conditions is reported.
\end{abstract}

Keywords: 1-[(2-Oxonaphthalen-1(2H)-ylidene)methyl]urea; Condensation reaction Solvent-free conditions

Dihydropyrimidinones (DHPMs) have attracted considerable interest due to the promising biological and pharmacological properties as calcium channel blockers, antihypertensive agents, and anticancer drugs associated with this heterocyclic scaffold. ${ }^{1,2}$ Thus, the synthesis of such a heterocyclic nucleus is of considerable importance, and quite a number of synthetic modifications based on the Biginelli three-component condensation reaction of aldehyde, $\beta$-ketoester, and urea have been developed. ${ }^{3}$

In continuation of our green chemistry programme towards the synthesis of DHPM heterocyclic compounds, we found an unexpected product, namely 1-[(2-oxonaphthalen-1(2H)-ylidene)methyl]urea 4 of the Biginelli reaction of 2-hydroxy-1-naphthaldehyde with ethyl benzoylacetate and urea under hydrochloric acid-catalyzed and solvent-free conditions (Scheme 1). 
<smiles>O=Cc1c(O)ccc2ccccc12</smiles>

1<smiles>NC(=O)c1c(O)ccc2ccccc12</smiles>

3
$\mathrm{NH}_{2} \mathrm{CONH}_{2} \underset{70^{\circ} \mathrm{C}, 2 \mathrm{~h}}{\stackrel{\mathrm{HCl}}{\longrightarrow}}$

2

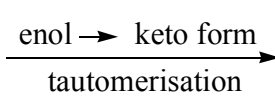

tautomerisation<smiles>NC(=O)NC=C1C(=O)C=Cc2ccccc21</smiles>

4<smiles>NC(=O)NC1C(=O)C=Cc2ccccc21</smiles>

4

\section{Scheme 1}

In comparative experiments, reactions of 2-hydroxy-1-naphthaldehyde $\mathbf{1}$ and urea $\mathbf{2}$ with or without ethyl benzoylacetate under hydrochloric-acid-catalyzed and solvent or solvent-free conditions afforded 4 as the only product. With ethyl or methyl acetoacetate, however, 4 turned out to be a minor product besides the major product of the Biginelli reaction.

It may be rationalized that $\mathbf{4}$ is the tautomer of $\mathbf{3}$ that resulted from dehydration condensation reaction of 2-hydroxy-1-naphthaldehyde and urea.

This novel reaction may find application in the synthesis of naphthalenylmethylureas which may be bioactively interesting substances.

\section{Experimental procedure}

\section{Method A}

A mixture of 2-hydroxy-1-naphthaldehyde 1 ( $0.86 \mathrm{~g}, 5 \mathrm{mmol})$, ethyl benzoylacetate (1.06 $\mathrm{g}, 5.5$ $\mathrm{mmol})$, urea $2(0.33 \mathrm{~g}, 5.5 \mathrm{mmol})$, and hydrochloric acid ( 2 drops) was heated at $70^{\circ} \mathrm{C}$ for $2 \mathrm{~h}$. Upon cooling, ethyl acetate-petroleum $(1: 1, \mathrm{v} / \mathrm{v})$ was added and a yellow precipitate was obtained, then filtered and recrystallized from ethanol to afford the title compound 4 as yellow crystals, $0.65 \mathrm{~g}$, yield $60.7 \%$, m.p. $179.3-180.8{ }^{\circ} \mathrm{C}$.

\section{Structural Characterization}

${ }^{1} \mathrm{H}$ NMR (Bruker Avance $\left.300 \mathrm{MHz}, \mathrm{DMSO}-d_{6}\right): \delta_{\mathrm{H}} 13.22$ (d, $\left.J=10.5 \mathrm{~Hz}, 1 \mathrm{H}, \mathrm{N}-\mathrm{H}\right), 9.01(\mathrm{~d}, J=$ $10.5 \mathrm{~Hz}, 1 \mathrm{H}, \mathrm{N}-\mathrm{H}), 7.97$ (d, $J=8.2 \mathrm{~Hz}, 2 \mathrm{H}), 7.81$ (d, $J=9.6 \mathrm{~Hz}, 1 \mathrm{H}, \mathrm{Ar}-\mathrm{H}-4), 7.63$ (d, J= 7.6 Hz, 1 $\mathrm{H}), 7.50-6.58(\mathrm{~m}, 3 \mathrm{H}), 6.60(\mathrm{~d}, J=9.6 \mathrm{~Hz}, 1 \mathrm{H}, \mathrm{Ar}-\mathrm{H}-3) \mathrm{ppm} .{ }^{13} \mathrm{C}$ NMR $\left(75 \mathrm{MHz}, \mathrm{DMSO}-d_{6}\right): \delta_{\mathrm{C}}$ 184.0, 154.3, 147.1, 141.9, 134.5, 129.9, 129.6, 126.9, 126.7, 124.9, 119.9, 108.3 ppm. IR (Bruker Tensor 27, KBr): $v_{\max } 3426(\mathrm{~N}-\mathrm{H}), 1741(\mathrm{C}=\mathrm{O}), 1620(\mathrm{~N}-\mathrm{C}=\mathrm{O}), 1584 \mathrm{~cm}^{-1}$. MS (Agilent 5973N MSD, EI, $70 \mathrm{eV}): \mathrm{m} / \mathrm{z}$ (\%) $214\left(\mathrm{M}^{+}, 44\right), 170$ (100), 115 (50). Elemental Anal. (Perkin Elmer PE 2400 II HONS) calcd for $\mathrm{C}_{12} \mathrm{H}_{10} \mathrm{~N}_{2} \mathrm{O}_{2}$ : C 67.28, $\mathrm{H}$ 4.71, N 13.08; found: C 67.26, H 4.60, N 13.04. 


\section{Method B}

A mixture of 2-hydroxy-1-naphthaldehyde 1 (0.86 g, $5 \mathrm{mmol})$, urea 2 (0.33 g, $5.5 \mathrm{mmol})$, and hydrochloric acid (2 drops) was heated at $100^{\circ} \mathrm{C}$ for $1 \mathrm{~h}$. Upon cooling, ethyl acetate-petroleum (1:1, $\mathrm{v} / \mathrm{v}$ ) was added and a yellow precipitate was obtained, then filtered and recrystallized from ethanol to give rise to 4 as yellow crystals, $0.49 \mathrm{~g}$, yield $45.5 \%$, m.p. $179.2-180.5{ }^{\circ} \mathrm{C}$.

Moreover, other conditions such as solvent-free catalyzed with ammonium chloride and in ethanol catalyzed with hydrochloric acid have also been investigated and $\mathbf{4}$ was also obtained.

\section{References}

1. Kappe, C. O. 100 Years of Biginelli Dihydropyrimidine Synthesis. Tetrahedron 1993, 49, 69376963.

2. Kappe, C. O. Recent Advances in the Biginelli Dihydropyrimidine Synthesis. New Tricks from an Old Dog. Acc. Chem. Res. 2000, 33, 879-888.

3. Ahmed, N.; van Lier, J. E. $\mathrm{TaBr}_{5}$-catalyzed Biginelli reaction: one-pot synthesis of 3,4dihydropyrimidin-2-(1H)-ones/thiones under solvent-free conditions. Tetrahedron Lett. 2007, 48, 5407-5409 and references cited therein.

(C) 2009 by the authors; licensee Molecular Diversity Preservation International, Basel, Switzerland. This article is an open-access article distributed under the terms and conditions of the Creative Commons Attribution license (http://creativecommons.org/licenses/by/3.0/). 